\title{
TURNAROUND MANAGEMENT THROUGH BUSINESS PROCESS RE-ENGINEERING FOR SBH HOTEL, BANDUNG, INDONESIA
}

\author{
Sarah Febe Stefani ${ }^{1}$ \& Deddy Priatmodjo K ${ }^{2}$ \\ 1,2Bandung Institute of Technology \\ (sarah_febe@sbm-itb.ac.id, deddypri@sbm-itb.ac.id)
}

\begin{abstract}
The fact that no company is immune to distress is indicates that business perform in a similar fashion to products. A company's failures or a passive reaction towards handling the decline would cause the company to end up in crisis. SBH Hotel has seen a continuous decline in occupancy rates from 2016 to 2019 from $70 \%$ to $51 \%$ and $27 \%$ after the COVID-19 pandemic hit. The hotel's sluggish reaction towards increasing competition and small improvements in management since its establishment in 1998, were not good enough to help them rebound and led them into their present crisis. Turnaround management that has been known to be the best strategy to save a company in crisis, is the proposed solution that this research paper recommends. The financial data collected, interviews and this researcher's observations in the gathering of the data and the use of International Turnaround Management Standard framework by Lymbersky will be applied in a bid to resolve the hotel's crisis. The International Turnaround Management Standard framework by Lymbersky was chosen as a solution due to its thorough coverage which makes it the suitable framework for the turnaround process. The framework covers areas which include, financial strategies, operational and others that the hotel needs to consider. Business process re-engineering will also help this researcher to determine the change in management processes that are required when developing the hotel's turnaround management action plan. This research paper will be a development from previous research regard its marketing strategy. Turnaround management will be done through Business Process Reengineering as a rethinking and redesign process. SBH Hotel expected to perform with better management process and provide customer with higher quality of services and products. SBH Hotel ability in earning outstanding guests' experience brought hotel more guest loyalty and help the hotel remain profitable.
\end{abstract}

KEYWORDS: Business Decline, Organizational Decline, Turnaround Management, Business Process Reengineering

\section{PURPOSE AND BACKGROUND}

SBH's failure to acknowledge and passive reaction towards the increase in competition in the market has caused them to face a crisis. Turnaround management which is the best strategy to save a company in crisis, has been proposed as a solution for the crisis. A turnaround is expected to give SBH Hotel a suite of crisis management strategies and a better and clearer direction which will improve hotel operations and guest loyalty.

\section{METHODOLOGY}

Both qualitative and quantitative methods were used to collect data for this study. Data collection, interviews, observations and a study of available literature will be used to come up with an appropriate turnaround management strategy for the SBH Hotel. The turnaround plan will make use of the International Turnaround Management Standard (ITMS) framework by Lymbersky. 
The ITMS framework will provide a suitable and comprehensive guide for the hotel's turnaround since ITMS covers all key areas including, financial and operational strategies that need to be considered. Additionally, business process re-engineering will be used to help this researcher to determine the changes in management processes that are required in developing the turnaround management action plan.

\section{FINDINGS}

Turnaround strategy that is required to be done in a holistic way through ITMS Framework by Lymbersky consist of four stages:

1. Stage 1: Pre-Turnaround Stage - Diagnostic Review Stage

In this stage, at the beginning the management analyze an elaborate business situation to gain an understanding with regard to the severe situation hotel have developed currently and define what root causes that support the current hotel situation.

2. Stage 2: Crisis Stabilization Stage - Change Management

Stage two, discuss about the alternative formulation suggested for $\mathrm{SBH}$ Hotel up to change management. New concept of heritage boutique smart hotel is suggested by the author considering the strategic location SBH Hotel has and the beauty of classic design of the building. Renewal and redesigning its product quality, services, and hotel's design interior is encouraged. Organizational improvement done through training conducted and the hiring for a change agent. Retrenchment and 13-weeks cashflow are suggested to ensure a healthy cashflow.

3. Stage 3: Communication Procedures - Risk Management

Stage three explains the importance of communication among its stakeholder to gain their support and trust. SBH Hotel's management needs to gain acknowledgement for its risk management that could incur costs.

4. Stage 4: Closing the Turnaround

Last stage is the act of the management to keep a journal of turnaround management process for future benefit

\section{CONCLUSION}

Passive reaction and employee inability in acknowledging the change of rapid market needs and competition, SBH Hotel has been struggling with its business and organisational decline that has led the business into its present crisis and it is in desperate need of turnaround management.

The turnaround management concepted through ITMS framework developed by Lymbersky due to its comprehensive coverage for the business.

Turnaround strategy that is required to be done in a holistic way through the use of an ITMS Framework by Lymbersky which can be summarised as follows:

1. Stage 1: Pre-Turnaround Stage - Diagnostic Review Stage

In this stage, the management elaborates a business situation, reasons that support SBH Hotel face crisis stage of decline. 
2. Stage 2: Crisis Stabilization Stage - Change Management

Stage two discuss about a formulation for alternatives suggested for SBH Hotel up to change management

3. Stage 3: Communication Procedures - Risk Management

Stage three shows the importance of communication among its stakeholder and gaining acknowledgement for its risk management that could incur costs.

4. Stage 4: Closing the Turnaround

Last stage is the act of the management to keep a journal of turnaround management process for future benefit.

\section{CONTRIBUTION/PRACTICAL IMPLICATIONS}

This study expects to create a clearer and more direct framework for documenting the turnaround management plans for hotels in any classification. Remembering the steps and stages that the management should take in this turnaround process can be implemented in general and this method could be used to help hotels survive the impact of the COVID-19 pandemic. Through this study, readers are expected to be able to understand and dissect their own hotel's shortcomings for then gain an insight and have an idea of what turnaround strategy is the most suitable for them based on ITMS framework provided in this research paper.

\section{ACKNOWLEDGEMENTS}

Author would like to send my outmost gratitude to Mr. Deddy P. Koesrindartoto as project counselor for the trust and encouragement to finish this project and Mr. Yayat Ruchiyat as the General Manager of SBH Hotel for the assistances to provide author with the data author needed.

\section{REFERENCES}

Lymbersky, C. (2011). Introducing the International Turnaround Management Standard. Turnaround Management Journal, 7-11.

Shein, J. B. (2011). Reversing the slide: A strategic guide to turnarounds and corporate renewal. San Francisco: John Wiley and Sons.

Solnet, D. J., Paulsen, N., \& Cooper, C. (2010). Decline and turnaround: A literature review and proposed research agenda for the hotel sector. Current Issues in Tourism, 13(2), 139-159. 